\title{
22. 低層集合住宅地の景観計画に関する研究
}

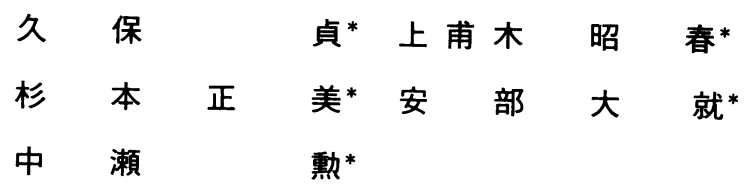

Human and Space Behavioral Systems Approach to Residential Environment, Landscape and Exterior Space in Low Rise Housing

Tadashi Kubo, Akiharu Kaminogi, Masami Sugimoto, Daishu ABE, Isao NAKASE

\begin{abstract}
摘要：本研究は，低層集合住宅地の居住者の住環境に対する認識構造と，その認識構造に係わる住宅地属性を明確 にすることを目的とした。調査は 6 住宅地で行い，その結果, 居住者の住環境に対する認識構造の特性が明確にさ れた。さらに, 居住者の住環境に对する認識構造に係わる住宅地属性としては, 敷地面積, 戸数密度, 建蔽率, 地 形タイプ等の住宅地計画における基本的要因が抽出された。
\end{abstract}

\section{1. 研究目的}

本研究は，低層集合住宅地の居住者の住環境に対する 認識構造と, その認識構造に係わる住宅地属性を明確に するてとを目的としている。居住者の住環境に対する諸 意識は, 現時点での居住者の住環境に対する認識の仕方 と, 認識の形成過程を示唆すると考えられる居住者の住 環境に対する認識の変化より把握しようとした。これら の分析結果をもとに, 低層集合住宅地の居住者が抱く総 括的な住環境のイメージと, 住宅地間で評価の異なる意 識については, 住宅地属性との関連性を把握しようとし た。

\section{2. 調查概要}

(1) 調査内容

居住者の住環境に対する諸意識の調查項目は, 意識調 查に先立って行なった実態調查結果を踏まえ，その調査 員によるブレーンストーミングにより設定した。すなわ ち, 住環境に対する設問項目として“自分の住まいとし ての愛着感”に関連すると考えられる11項目を設定した (表一 3 参照)。また, 時間経過の中での住環境の変化に 対する設問項目として“住みでてちの変化”に関連する と考えられる10項目を設定した（表一 4 参照）。

設問項目に対する評価ランクは，表一 $3 ， 4$ 亿示すよ
うに，その感じ方程度および変化程度をそれぞれ 5 段階 に分けた。なお，調査は直接面接法で行ない，数回訪問 して不在の場合は, 留置法で行なった。

(2) 調查対象住宅地

調查対象住宅地は, 実態調查した23住宅地の中から,

\section{表一 1 調查対象住宅地の概要}

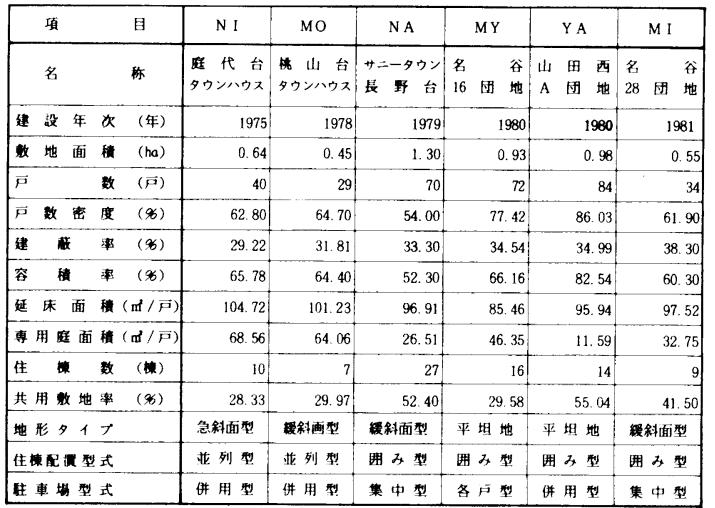

表一 2 調査サンプル数

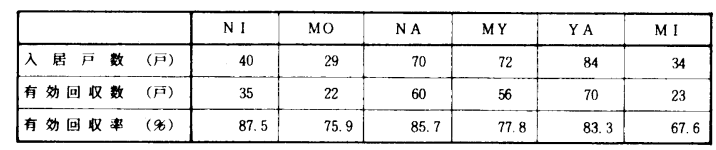

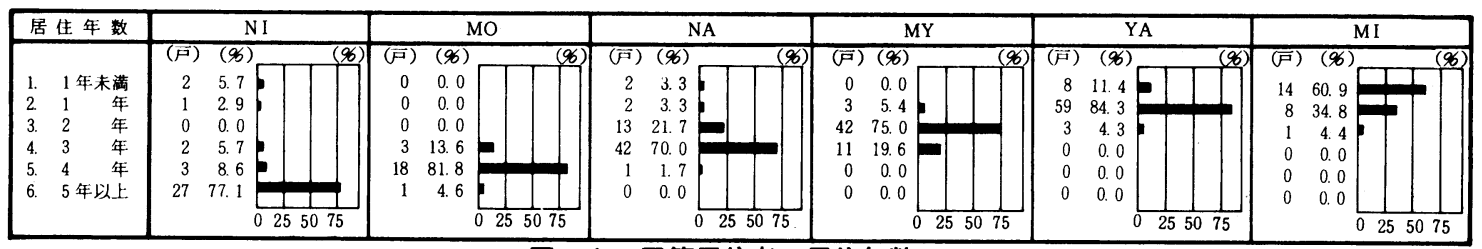

図-1 回答居住者の居住年数

\footnotetext{
${ }^{*}$ 大阪府立大学宸学部
} 
表一 3 住環境の設問項目に対する反応結果

\begin{tabular}{|c|c|c|c|c|c|c|c|c|}
\hline 凡 & $\begin{array}{l}\text { 七段：平均 } \\
\text { 下段：漂偏差 }\end{array}$ & N I & MO & NA & MY & YA & M I & 全 体 \\
\hline \multirow{2}{*}{1} & 自分の住まいとしての & 4. 00 & 4. 18 & 3. 98 & 4. 13 & 3. 90 & 3. 74 & 3. 99 \\
\hline & 娄管感 & 1. 31 & 0.89 & 1. 28 & 1.00 & 1. 06 & 1. 29 & 1. 15 \\
\hline & 位及 & 4. 26 & 4. 32 & 4. 25 & 4. 13 & 4. 10 & 4. 09 & 4. 18 \\
\hline & & 0.81 & 0.82 & 0.85 & 0.95 & 0.99 & 1.10 & 0.93 \\
\hline \multirow{2}{*}{\multicolumn{2}{|c|}{3 日常生活の便利さ }} & 3. 20 & 2. 68 & 2. 22 & 4. 54 & 2. 99 & 3. 78 & 3.21 \\
\hline & & 1. 21 & 0.92 & 1.25 & 0.84 & 1. 22 & 1. 10 & 1. 39 \\
\hline \multirow{2}{*}{\multicolumn{2}{|c|}{4 近所万きあいのし易さ }} & 4. 06 & 3. 86 & 3. 43 & 3. 84 & 3. 70 & 3. 96 & 3. 75 \\
\hline & & 0.98 & 0.92 & 1. 17 & 1. 13 & 1.11 & 1. 00 & 1. 11 \\
\hline \multirow{2}{*}{\multicolumn{2}{|c|}{5 住宅地の落ちつき }} & 4. 31 & 4. 14 & 4. 12 & 3. 84 & 3. 81 & 3. 96 & 3. 99 \\
\hline & & 0.89 & 1. 10 & 1. 17 & 1. 10 & 1.05 & 1. 00 & 1.08 \\
\hline \multirow{2}{*}{\multicolumn{2}{|c|}{6 一个建の家の豕用冬 }} & 2. 86 & 2. 91 & 2. 88 & 2. 68 & 3.26 & 2. 87 & 2. 94 \\
\hline & & 1.27 & 1.47 & 1. 55 & 1. 35 & 1. 38 & 1. 48 & 1. 43 \\
\hline \multirow{2}{*}{\multicolumn{2}{|c|}{7 身近な緑の取き }} & 4. 57 & 4. 45 & 4. 48 & 3. 98 & 4. 04 & 4.48 & 4. 27 \\
\hline & & 0.65 & 0.94 & 0.85 & 1. 36 & 0.99 & 0.97 & 1.04 \\
\hline \multirow{2}{*}{\multicolumn{2}{|c|}{$\begin{array}{l}8 \text { 住乇地のつくりに対す } \\
\text { る蜆しみ易さ }\end{array}$}} & 3. 89 & 4. 00 & 3. 80 & 3. 50 & 3.57 & 3.87 & 3.71 \\
\hline & & 1.01 & 0.90 & i. 19 & 1. 18 & 1.05 & 1.23 & 1.13 \\
\hline & 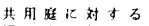 & 3. 83 & 3.77 & 3. 05 & 3.25 & 3. 53 & 3. 57 & 3. 42 \\
\hline & 好 未表 L & 1. 18 & 1. 13 & 1. 22 & 1. 30 & 1. 17 & 1. 14 & 1. 23 \\
\hline & $\rightarrow \quad$ & 3. 23 & 3. 55 & 2. 80 & 3. 13 & 3. 37 & 2. 91 & 3. 15 \\
\hline & L lf 0 & 1. 40 & 1. 37 & 1. 42 & 1. 50 & 1.41 & 1. 32 & 1.44 \\
\hline \multirow{2}{*}{\multicolumn{2}{|c|}{$11>>1 \times 3=$}} & 3. 86 & 3. 68 & 3. 62 & 3. 13 & 3. 13 & 3. 74 & 3. 43 \\
\hline & & 1.17 & 1.06 & 1. 32 & 1. 30 & 1.45 & 1.07 & 1. 33 \\
\hline
\end{tabular}

表一 4 住環境の変化の設問項目に対する反応結果

\begin{tabular}{|c|c|c|c|c|c|c|c|c|}
\hline 凡 & $\begin{array}{ll}\text { 上段：平均 } \\
\text { 卜段：缥着 }\end{array}$ & N I & MO & $\mathrm{NA}$ & MY & YA & M I & 全 体 \\
\hline & 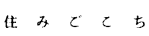 & 3. 97 & 3. 82 & 3. 60 & 3. 59 & 3. 64 & 3. 65 & 3. 68 \\
\hline 2 & 实外空閣の使い腾手 & $\begin{array}{l}3.49 \\
0.91\end{array}$ & 3. 27 & 3. 00 & 3. 29 & 3. 34 & 3. 52 & 3. 28 \\
\hline & フライハシ - & $\begin{array}{l}3.26 \\
0.73\end{array}$ & $\begin{array}{l}3.18 \\
0.72\end{array}$ & $\begin{array}{l}\text { 3. } 05 \\
0.94\end{array}$ & $\begin{array}{l}3.00 \\
0.85\end{array}$ & $\begin{array}{l}3.03 \\
0.86\end{array}$ & $\begin{array}{l}3.39 \\
0.71\end{array}$ & $\begin{array}{l}3.10 \\
0.85\end{array}$ \\
\hline & $\begin{array}{l}\text { 各戸の去関未かりや尃庭の使われ方 }\end{array}$ & $\begin{array}{l}3.71 \\
0.97\end{array}$ & $\begin{array}{l}3.82 \\
0.98\end{array}$ & $\begin{array}{l}\text { 3. } 10 \\
1.08\end{array}$ & $\begin{array}{l}3.77 \\
1.00\end{array}$ & $\begin{array}{l}\text { 3. } 50 \\
0.94\end{array}$ & $\begin{array}{l}\text { 3. } 52 \\
0.93\end{array}$ & $\begin{array}{l}3.52 \\
1.02\end{array}$ \\
\hline & 共用庭の利用のされ方 & $\begin{array}{l}3.43 \\
0.87\end{array}$ & $\begin{array}{l}\text { 3. } 00 \\
0.52\end{array}$ & $\begin{array}{l}2.66 \\
0.96\end{array}$ & $\begin{array}{l}3.16 \\
0.77\end{array}$ & $\begin{array}{l}\text { 3. } 36 \\
0.83\end{array}$ & $\begin{array}{l}3.26 \\
0.61\end{array}$ & $\begin{array}{l}3.13 \\
0.86\end{array}$ \\
\hline & $\begin{array}{l}\text { 生活の地ししての落ち } \\
\text { つきゃ司团 }\end{array}$ & $\begin{array}{l}3.89 \\
0.85\end{array}$ & $\begin{array}{l}\text { 3. } 77 \\
0.95\end{array}$ & $\begin{array}{l}\text { 3. } 77 \\
0.97\end{array}$ & $\begin{array}{l}3.68 \\
1.00\end{array}$ & $\begin{array}{l}3.70 \\
1.00\end{array}$ & $\begin{array}{l}3.43 \\
0.82\end{array}$ & $\begin{array}{l}3.72 \\
0.97\end{array}$ \\
\hline & 近所万きあい & $\begin{array}{l}3.66 \\
0.83\end{array}$ & $\begin{array}{l}3.73 \\
0.86\end{array}$ & $\begin{array}{l}3.72 \\
0.88\end{array}$ & $\begin{array}{l}3.75 \\
1.04\end{array}$ & $\begin{array}{l}3.83 \\
0.88\end{array}$ & $\begin{array}{l}3.91 \\
0.88\end{array}$ & $\begin{array}{l}3.76 \\
0.91\end{array}$ \\
\hline & 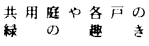 & $\begin{array}{l}\text { 4. } 51 \\
0.69\end{array}$ & $\begin{array}{l}4.41 \\
0.72\end{array}$ & $\begin{array}{l}3.77 \\
1.05\end{array}$ & $\begin{array}{l}3.86 \\
1.03\end{array}$ & $\begin{array}{l}4.01 \\
0.78\end{array}$ & $\begin{array}{l}3.78 \\
0.83\end{array}$ & $\begin{array}{l}4.00 \\
0.93\end{array}$ \\
\hline & 周刃地城とのなじみ & $\begin{array}{l}3.74 \\
1.02\end{array}$ & $\begin{array}{l}4.14 \\
0.76\end{array}$ & $\begin{array}{l}3.62 \\
0.86\end{array}$ & $\begin{array}{l}3.75 \\
0.89\end{array}$ & $\begin{array}{l}3.53 \\
0.84\end{array}$ & $\begin{array}{l}3.78 \\
0.78\end{array}$ & $\begin{array}{l}3.70 \\
0.88\end{array}$ \\
\hline & 待亚みの西 & $\begin{array}{l}3.83 \\
0.94\end{array}$ & $\begin{array}{l}3.77 \\
1.00\end{array}$ & $\begin{array}{l}3.68 \\
1.07\end{array}$ & $\begin{array}{l}\text { 3. } 55 \\
0.73\end{array}$ & $\begin{array}{l}3.60 \\
0.95\end{array}$ & $\begin{array}{l}\text { 3. } 48 \\
0.71\end{array}$ & $\begin{array}{l}3.64 \\
0.93\end{array}$ \\
\hline
\end{tabular}

\begin{tabular}{|c|c|c|c|c|}
\hline 悪 & どば & どい & どば & 良 \\
\hline$<$ & ち悪 & $5_{i}$ & 声良 & $<$ \\
\hline な & 加 & 5 & 汃 & な \\
\hline$?$ & $\begin{array}{l}c^{\infty} \\
w^{2}\end{array}$ & $\varepsilon^{な}$ & $\begin{array}{c}\varepsilon^{\infty} \\
\omega^{\prime}\end{array}$ & ᄀ \\
\hline た & えた & 屯い & えた & た \\
\hline$(1.0)$ & $(2.0)$ & (3.0) & $(4.0)$ & $(5.0)$ \\
\hline
\end{tabular}

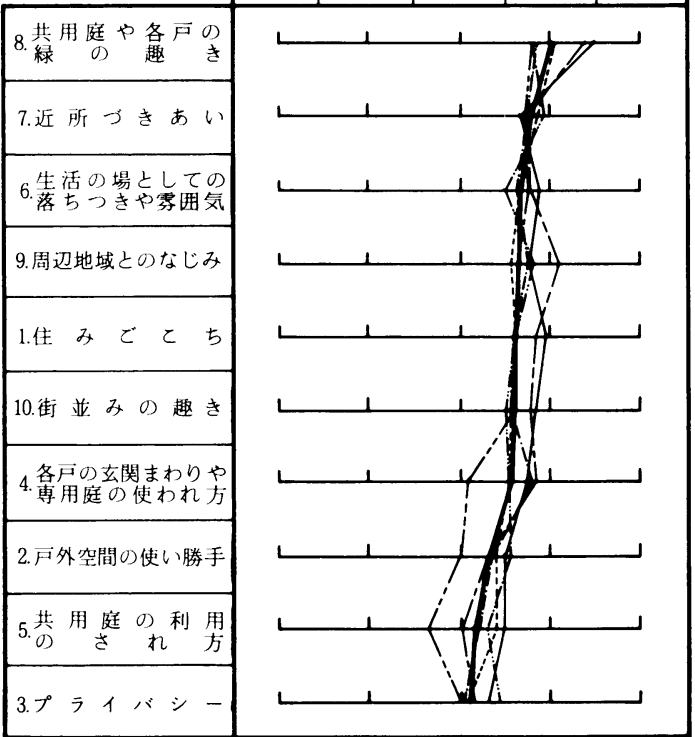

図一 3 住環境の変化に対する反応プロフィール

図一2 住環境に対する反応プロフィール 
地域性, 建設年次, 地形タイプ; 住棟配置型式等の諸属 性を考慮して6住宅地を選出した。6 住宅地の諸属性は 表一 1 亿示す。

(3) 調查期間と有効回収率

調查は, 昭和57年 7 月に実施し, 有効回収率は表一 -2 に示す。

\section{3. 住環境の認識構造}

ここでは, 居住者の住環境に対する認識構造を, (1)反 応プロフィールからの認識傾向, (2)設問項目間の関連性, (3)住宅地間での認識傾向の相違, (4)時間軸からの認識傾 向等から解析した。居住者の住環境に対する諸意識の調 查結果は, 表一 3,4 亿示す。な打 6 住宅地の回答居住 者の居住年数は, 図一 1 亿示す。

（1）反応プロフィールからの認識傾向

居住者の住環境に対する諸意識の調查結果を, 全体で 評価の高い設問項目順に並べて, 住宅地別にも図化した あのが, 図一2, 3 である。

(i) 住環境に対する認識傾向

居住者の住環境に対する全体的な認識傾向は, “自分 の住まいとしての愛着感”，“住みごてちの良さ”ゃ“身 近な緑の趣き”，“住宅地の落ちつき”については, “ど ちらかといえば感じる”という傾向を示しているが, “定 住の意志” , “一戸建の家の雾囲気”については, “よ゙ ちらともいえない”という傾向で，相対的に評価が低い。 その他の項目は, 上記の項目の中間的な評価であるが,

“プライバシー”, “共用庭に対する好ましさ”, “日常生 活の便利さ”については, 住宅地間でのばらつきが大き い。

(ii）住環境の変化に対する認識傾向

住環境の変化住対しては, “共用庭や各戸の緑の趣き”, “近所づきあい”等が, 入居時に比べ“どちらかといえ ば良くなっだという傾向を示し，時間経過とともに日 常生活を介して場や人々とのつながりが深くなっている ととがわかった。一方, 外部空間の使われ方に関連する 項目は相対的に評価が低く, 特に “戸外空間の使い勝手”,

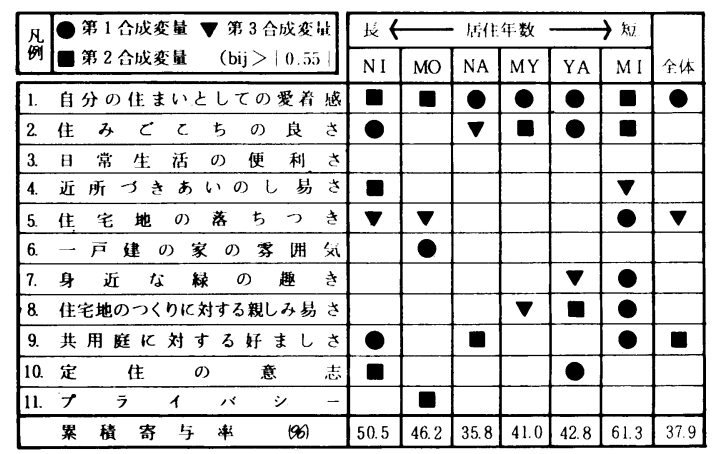

図ー4 住㻴境の設問項目のグループ化
“共用庭の利用のされ方”は, “どちらと屯いえない”と いう傾向に寄って抢り, 場とその利用の対応関係は必ず し屯良い方向に進んでいないてとがわかった。他の項目 では, "プライバシー"については, 入居当時とほとんど 変わらない傾向を示し, それ以外は“どちらかといえば 良くなった”に寄った傾向を示している。

(2) 設問項目間の関連性

ここでは, 設問項目間の関連性すなわち, 評価に際し て同様の变動を示す項目のグループ化を, バリマックス 法により住宅地別および全体について行なった。解析結 果は, 図一 4,5 亿示すと抢りで, 第 3 合成変量までに ついて, それとの合成変量の值が $|0,55|$ 以上の項目を 図示している。ての解析結果より, 住環境およびその変 化汶対する諸項目について共通にいえるてとは, 第 3 合 成変量までの累積寄与率が低く, 各設問項目が単独の変 動を示す傾向がうかがえる。ただし住宅地別にみると若 干項目のグループ化がみられ, 以下その傾向について述 べる。

(i) 住環境に対する設問項目間の関連性

“自分の住まいとしての愛着感” との係わりをみてみ ると, この項目と同じグループ汇属する項目はN I (庭 代台タウンハウス) では, “近所づきあいのし易さ”, “定 住の意志”, MO (桃山台タウンハウス) では, “プライ バシー", Y A (山田西A団地) では, “住みでてちの良 さ”, “定住の意志”, M I (名谷28団地) では, “住みで こちの良さ”が抽出され, “自分の住まいとしての愛着 感” の感じ方には, 近所づきあいやプライバシーに代表 される隣人関係とのつながりがみられると同時に, “定 住の意志”との関連むみられ, 住環境評価におけるキー ワードとして再認識できる。

(ii) 住環境の変化住対する設問項目間の関連性

“住みごこち"の変化との係わりをみると，N I では “生活の場としての落ちつきや雾囲気”, “共用庭や各戸 の緑の趣き”, MI では, “戸外空間の使い勝手”, “プライ バシー", “共用庭の利用のされ方", “街亚みの趣き”が 抽出できる。その傾向は, 居住年数の長いN I では時間

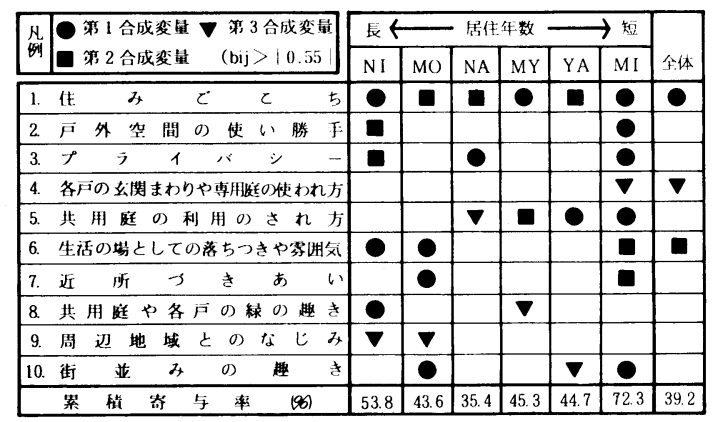

図一 5 住環境の変化の設問項目のグループ化 
経過の中での緑の変化, 居住年数の短いM I ではさほよ゙ 長い時間経過を要さない戸外空間の使われ方やプライバ シー等の変化とのつながりをむっているといえる。

(3) 住宅地間での認識傾向の相違

こてでは, 居住者の住環境に対する諸意識の調査結果 に，住宅地間で有意な差があるか否かの検定を，分散分 析法で行なう。すなわち, 設問項目に対する反応結果が, 全住宅地共通の認識傾向として捉えられるか否かを検討 するあのである。分散分析の結果は, 表一 5 ，6亿示す。

住宅地間で有意な差が認められる項目は, 住環境に対 する設問項目では, “日常生活の便利さ”, “身近な緑の 趣き”, “共用庭に対する好ましさ”, “プライバシー”の 4 項目, 住環境の変化に対する設問項目では, “共用庭 の利用のされ方”, “共用庭や各戸の緑の趣き”の 3 項目 であった。その他の項目では, 当調查住宅地間では有意 な差が認められず, 共通の認識傾向を示すあのであると いえよう。

\section{表一 5 住環境の住宅地間での有志差検定}

\begin{tabular}{|c|c|c|c|}
\hline & 項 & 值 & 有意水薄 \\
\hline 1 & 自分の住まいとしての爱着感 & 0.57 & - \\
\hline 2 & 住 みとと ち の 良さ & 0.40 & - \\
\hline 3 & 日 常 生活 の 便利さ & 26.95 & 0.01 \\
\hline 4 & 近所つきあいのし易さ & 1.84 & - \\
\hline 5 & 住宅地 の 落 ちつき & 1.47 & - \\
\hline 6 & 一戸建の家の荤用気 & 1.11 & - \\
\hline 7 & 身 近 な 緑 の 趣き & 3. 06 & 0.05 \\
\hline 8 & 住宅地のつくりに対する親しみ易さ & 1.24 & - \\
\hline 9 & 共用庭に対する好末しさ & 2.66 & 0.05 \\
\hline 10 & 定 住 の 意 & 1.53 & - \\
\hline 11 & 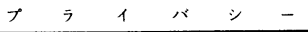 & 2. 76 & 0.05 \\
\hline
\end{tabular}

\section{（4）時間軸力らの認識傾向}

住環境に対する設問項目は，居住者自身の心的イメー ジに係わる項目と住環境の具体的な場のイメージに係わ る項目に分けられる。乙てでは, 心的イメージに係わる 項目と居住者自身が受けとめた住環境の変化に対する認 識傾向との関連性を相関係数の検定で分析した。相関係 数の検定結果は, 図一6に示す。

まず“自分の住まいとしての愛着感”と“定住の意志” の認識傾向は同样な傾向を示しており, それらは多くの 項目と関連している。さらに“自分の住まいとしての愛 着感”と“定住の意志”は, 住宅地別にみると, 居住年 数の短い住宅地では, 多様な住環境の変化に対応して評 価されているのに対して, 居住年数の長いN I では, 特 定の住環境の変化に対応して評価される傾向にある。”日 常生活の便利さ”は，時間の変化による影響が少ない。

“住みごてちの良さ”は，多くの項目と関連するが，住 宅地間で関連する項目は異なる。“近所づきあい”、“プ

\section{表一6 住璄境の変化の住宅地間での有意差検定}

\begin{tabular}{|c|c|c|c|}
\hline & 項 & $\mathrm{F}$ & 有意水䇤 \\
\hline 1 & 住 み $\quad$ み $\quad$ 己 5 & 0.91 & - \\
\hline 2 & 戸 外空間 の使い勝手 & 1.85 & - \\
\hline 3 & $\begin{array}{llllll} & \text { ラ } & 1 & \text { ハ } & \text { シ } & -\end{array}$ & 1.13 & - \\
\hline 4 & 各闩の玄関まわりや尃用庭の使われ方 & 3. 45 & 0.01 \\
\hline 5 & 共用庭の利用のされ方 & 5. 98 & 0.01 \\
\hline 6 & 生活の場としての落ちつきや聁用気 & 0.67 & - \\
\hline 7 & 近 所 つ き あ & 0.33 & - \\
\hline 8 & 共用庭や各戸の緑の趣き & 4.51 & 0.01 \\
\hline 9 & 周辺地域とのなじみ & 1.81 & - \\
\hline 10 & 街 並 み & 0.66 & - \\
\hline
\end{tabular}

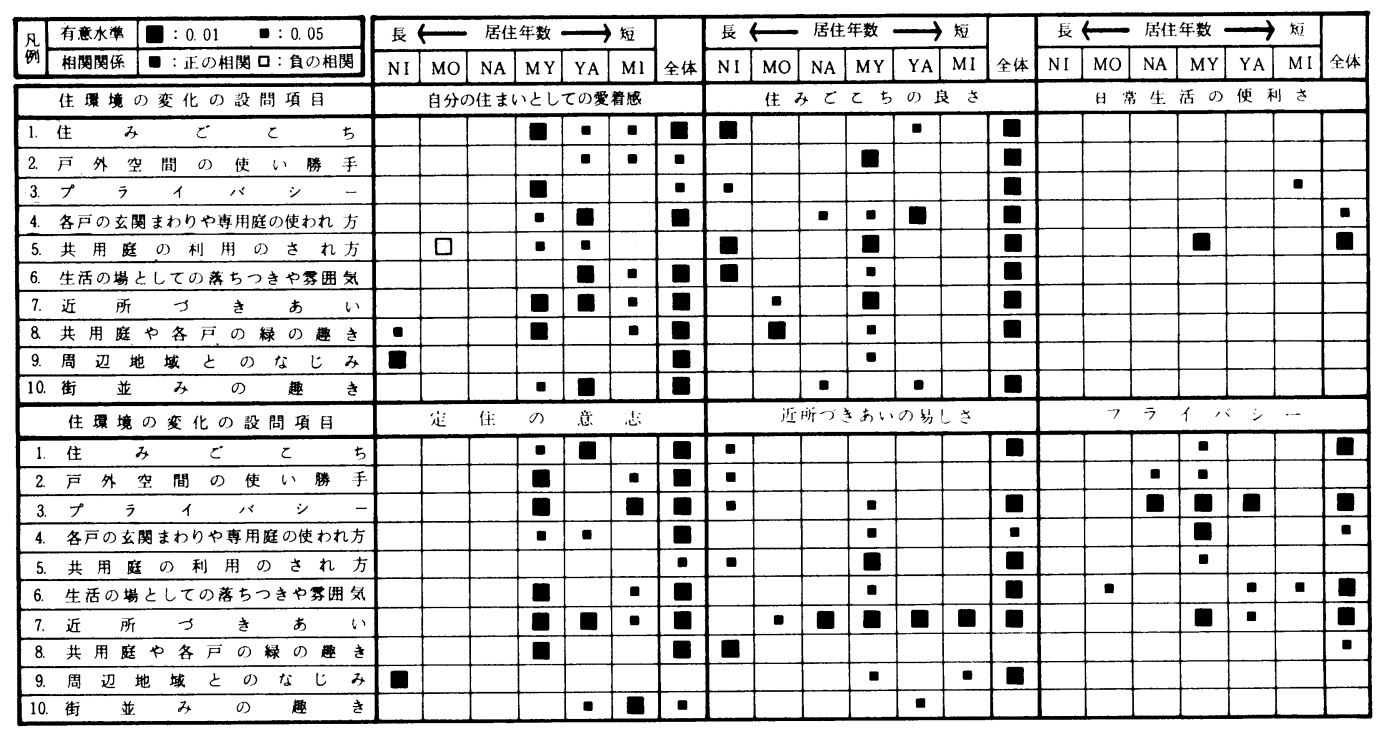

図一6 住羁境の設問項目と住環境の変化の設問項目との相関係数の検定 
ライバシー"に関しては，住宅地間で関連する項目は異 なるが，それらはともに近所づきあいやプライバシーの 変化に関連している。乙のととは,コミュニティとプラ イバシーの問題が, 表裏一体のあのであるととを物語っ ている。

\section{4. 住環境の認識構造と住宅地屈性との関連性}

前項では, 住環境の認識構造について解析したが, こ こではその結果を踏まえ，住宅地間で有意な差が認めら れた項目と住宅地属性との関連性を検討する。すなわち, (1)住宅地間での各設問項目の認識程度を比較し, いづれ の住宅地間で有意な差があるかを把握する一方, (2)各設 問項目の認識程度と住宅属性との関連性を検討し, 関連 の認められた住宅地属性について, 係わり方の傾向を検 討する。

(1) 住宅地間での各設問項目の認識程度の比較

住宅地間で有意な差が認められた各設問項目について, 最小有意差の検定を行なった結果は，図一 7 亿示す。住 環境の設問項目では，“日常生活の便利さ”は，住宅地 間で最も多くの差がみられた。たとえば, MY（名谷16 団地）は, 他の住宅地と比べ 0.01 の有意水準で評価が 高い。他の項目では, すべてN I の評価が高い。N I は, “身近な緑の趣き”, “プライバシー”では, Y A, MY に比べ, “共用庭に対する好ましさ”では, MY, N A （サニータゥン長野台）に比へ， 0.01 または 0.05 の有 意水準で評価が高い。一方, 住環境の変化の設問項目で は, “各戸の玄関まわりや専用庭の使われ方”, “共用庭 の利用のされ方”の変化について, N Aは, それぞれM I, MOを除く他の住宅地に比へ 0.01 または 0.05 の有 意水準で評価が低い。“共用庭や各戸の緑の趣き”の変
化については，N I，MOが，それぞれMO，Y Aを除 く他の住宅地に比べ 0.01 または 0.05 の有意水準で評価 が高い。以上の住宅地間の有意差の検定結果を踏まえ, 以下住宅地属性との関連性について述べる。

（2）各設問項目の認識程度と住宅地属性との関連性

住宅地間で有意な差が認められた各設問項目之住宅地 の量的属性および質的属性との関連性の検討は, それぞ れ分散分析およびグラフ解析により行なった。その結果 は, 図一8に示すとおりで, “日常生活の便利さ”, , “共 用庭の利用のされ方”以外の項目では, 数種の住宅地属 性との関連性が認識できた。

こてで, 各設問項目に関連する住宅地属性としては, 抽出された住宅地属性間の従属性を考虑して, 図一 9 亿 示す住宅地属性を抽出し,その係わり方の傾向を検討した。

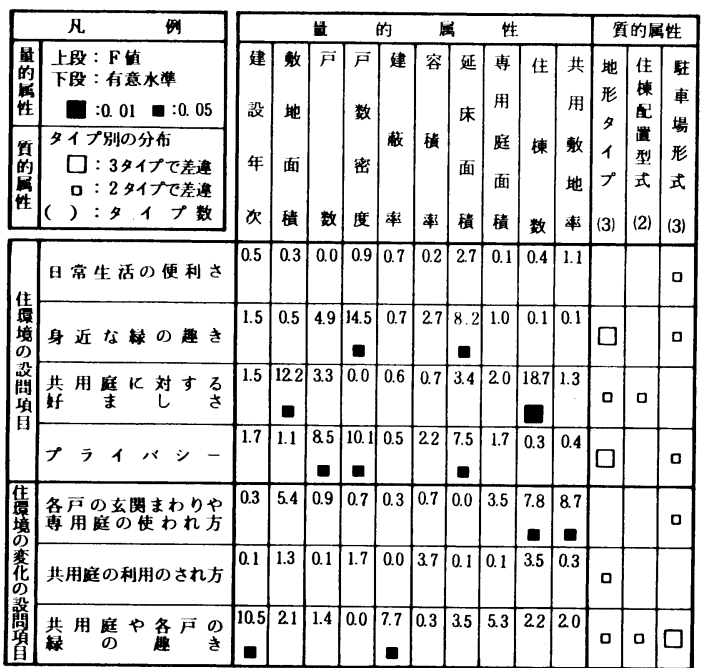

图一8 各設問項目と住宅地属性との関連性の検討

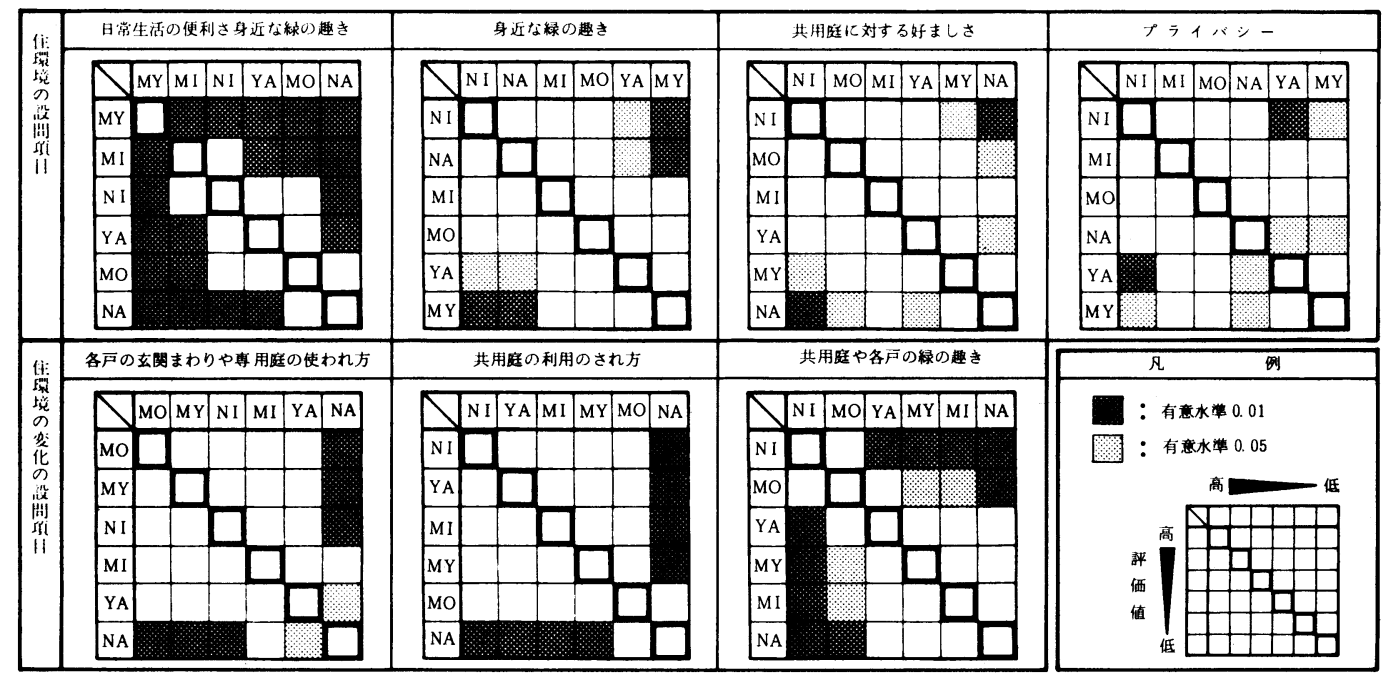

図ー7 各設問項目の住宅地間での有意差の検定 
まず “身近な緑の趣き”では, 戸数密度が低い方が高 い評価を受ける傾向にあり, 住宅地間での有意差の検定 からあ戸数密度が約80（戸/ha）のMY, Y A に比へ, それが約60（戸/ha）のN I, MOの評価は 0.01 の有 意水準で高い。地形タイプ別にみると, 傾斜地に立地す る住宅地の方が評価が高く, 急斜面型の N I は, 平担地 型の Y A, MYに比べ 0.01 または 0.05 の有意水準で評 価が高い。

“共用庭に対する好ましさ”では, 敷地面積が比較的

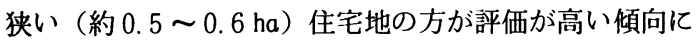
ある。

"プライバシー"では, 戸数密度が低い方が評価が高 い傾向にあり，地形タイプ別にみると，平担地型の住宅 地の評価が低く, 急斜面型の住宅地とは 0.01 または 0 . 05 の有意水準で差が認められた。

“各戸の玄関まわりや専用庭の使われ方”の变化では, 共用敷地率は低い住宅地, 住棟数は少ない住宅地の方が 良くなる傾向にある。ただし共用敷地率との関連では， $\mathrm{N} A$ と Y Aの評価に 0.05 の有意水準で逆の評価が認め られ,さらに検討する必要がある。

“共用庭や各戸の緑の趣き”の变化では, 建設年次は 古い住宅地，建蔽率は低い住宅地の方が良くなる傾向に ある。駐車場配置型式との関連をみると，併用型の住宅 地の方が相対的に良くなる傾向にあるが，併用型に属す する住宅地間であ 0.01 の有意水準で差が認められ，さ らに検討する必要がある。

以上，住宅地間で有意な差が認められた各設問項目と 住宅地属性との関連性について述べたが，乙れは今回調 查した 6 住宅地に扔ける結果であり，一般的法則性とは 必ずしあ言い難いが，その系口を示唆するあのといえる。 さらに，乙てで抽出された住宅地属性が，敷地面積，户 数密度, 建蔽率, 地形タイプといった住宅地計画の基本 的要因に及んでいることは，6住宅地からの結論とはい え，極めて注視すべき知見であると考える。

構造および外部空間の使われ方等との関連性屯検討して

\section{5. 今後の課題}

本報では，低層集合住宅地の居住者の住環境に対する 認識構造求よびその認識構造と住宅地属性との関連性を 述べたが，今後居住者属性との関連性屯検討していく必 要がある。さらに, 住環境の認識構造をより多面的に把 握する意味から，住環境の認識構造と街並み景観の認識

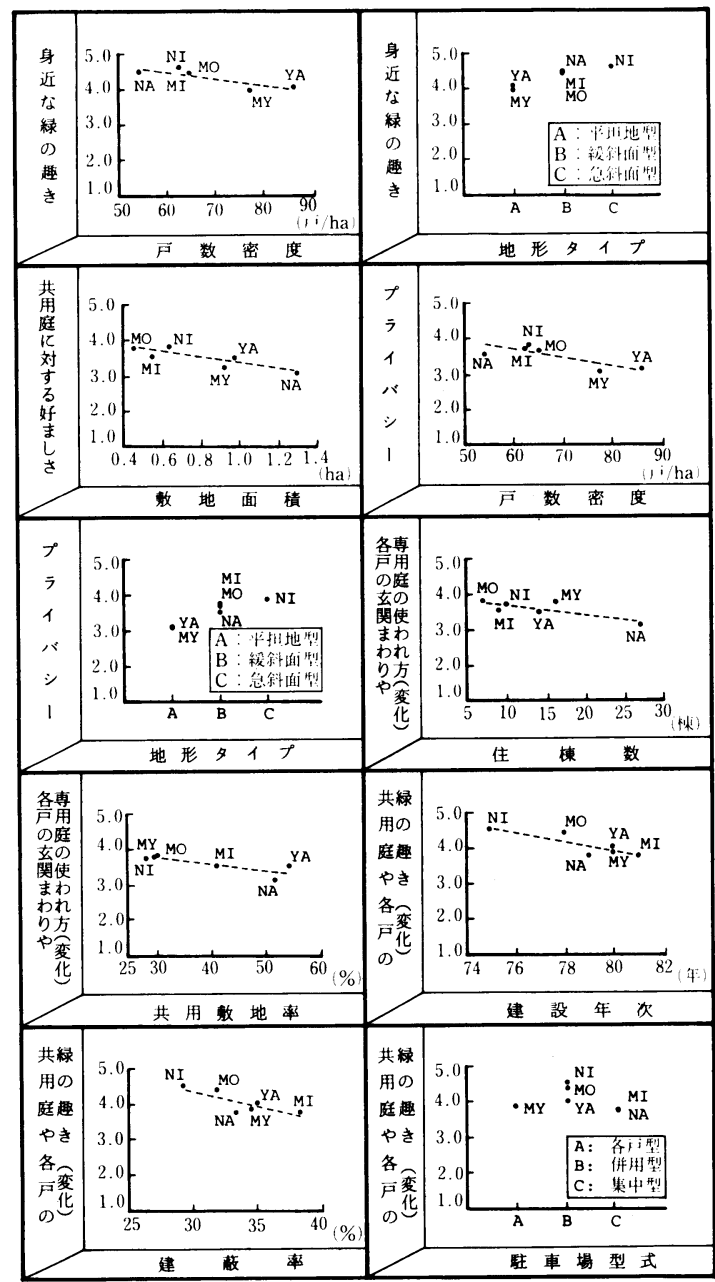

図一9 各設間項目と住宅地属性との関連性

いく予定である。

なお, 本研究は当研究室の大学院生, 学部生ならびに 住宅・都市整備公団関西支社の協力を得ていることを書 き加えておきたい。

\section{参 考 文 献}

1) 生沢雅夫（1980）：実験計画：新曜社

2 ）芝 祐順 (1972)：相関分析法：東京大学出版会

3) 芝 祐順（1981）：統計的方法 II：新曜社

4 ）久保 貞他（1982：低層集合住宅地の外部空間設計 亿関する研究：住宅・都市整備公団（印刷中）

Summary : Even though the resident's attitude towards dweling comfort was somewhat positive, the intent of long term habitation was low. The elements of the environment that relate most strongly to the resident's cognition of his/her environment are a) size of site, b) topography, c ) amount of building coverage, and d) building density. These elements, then, considered as basic components of the residential planning process. 